\title{
A HISTORY AND GEOGRAPHY OF CONTEMPORARY ARCHITECTURE
}

\author{
A B S T T R A C T
}

History is the study of the past described in written documents. Prehistory is the history of human culture prior to written documents and post-history is the period in which the end of human development is reached. Contemporary history, a subset of modern history, describes the historical period from approximately 1945 to the present. Although the term 'contemporary history' has been in use since at least the early nineteenth century, its usage changed in the twentieth century.

The continuous subduction process causes frequent earthquakes in Japan. The Japanese islands are also affected by typhoons and global warming. Although a country affected by numerous natural disasters, it recovers relatively quickly and is considered safe. The history of contemporary architecture is not related to natural disasters in the West. In Japan, however, it is related to earthquakes. The history of contemporary architecture in Japan should be written taking into account the phenomenon of earthquakes or at least the way in which contemporary architects have addressed this issue. After the peak of postmodernism and deconstructivism, some Japanese architects started holding traditional culture and nature in high regard, while discontinuing postmodern classicism. It is meaningful to pay attention to the history and geography of the contemporary architecture in Japan

\section{Haruhiko Fujita} from this perspective.

Kobe Design University, Osaka University 


\section{INTRODUCTION}

The general theme of the $21^{\text {st }}$ International Congress of Aesthetics entitled "Possible Worlds of Contemporary Aesthetics: Aesthetics between History, Geography and Media" is most significant. Both history and geography have been globalised since the fifteenth century when the Age of Discovery started and, even more so, since the first half of the twentieth century which saw two world wars. However, there are also a variety of histories and geographies all over the world and various attitudes toward history and geography among architects.

Human geography and history are closely linked. Physical geography deals with the study of processes and patterns in the natural environment. Although it is not closely linked with history, physical geography is also important to understand architectural history and the contemporary architecture of each country. At some point in the twenty-first century, the usage of the terms "contemporary history" and "contemporary architecture" may change again. (1)

\section{THE HISTORY OF CONTEMPORARY ARCHITECTURE}

"The History of Contemporary Architecture" may appear to be a rather strange title for a paper in the twentieth century. In the twenty-first century, almost seventy-five years after 1945, it is perhaps more understandable to talk about its outline by using the title "A History of Contemporary Architecture" and the three -isms: Modernism, Postmodernism, and Deconstructivism. Modern architecture emerged at the end of the nineteenth century because of innovations in technology and building materials and from a desire to break away from past architectural styles. Before the nineteenth century, each architectural style lasted for at least half a century, or as seen in the Middle Ages for more than a few centuries. However, the length of time for each style after the Middle Ages became increasingly shorter.

In Europe, Renaissance architecture was designed and constructed between the early fifteenth and late sixteenth centuries in different regions. Baroque architecture lasted from the late sixteenth century to mid-eighteenth century in Europe and Latin America. The next style in the West, Rococo, prominent from the early through to the late eighteenth century, was much shorter. Neoclassicist architecture lasted much longer from the mid-eighteenth century or even from the early eighteenth century as a reaction to the Rococo style. It was a forerunner of the revivalist movements of the nineteenth century. 
The nineteenth century was a century of revivalism or revivalisms in which various styles from the Classical, Middle, and Modern ages were revived. The length of each revivalism was a few decades. The Greek Revival was an architectural movement of the late eighteenth and early nineteenth centuries. The Gothic Revival lasted from the mid-eighteenth to the mid-nineteenth century, the Baroque Revival took place in the late nineteenth century, and the Rococo Revival in England only lasted for a few decades in the early nineteenth century. The Queen Anne Revival was a historicist architectural style of the late nineteenth and early twentieth centuries in English-speaking countries. It hardly included any elements typical of the actual architecture of Queen Anne's reign in the early eighteenth century. It was one of the last historical revival styles, freely using traditional forms of architectural elements. ${ }^{2}$

Modern architecture emerged at the end of these historical styles including nineteenth-century revivalisms, which had gradually and rapidly led to speeding up their style changes. It developed in the early twentieth century and became dominant across the world after World War II. Modern architecture is a historical reaction against historical styles up until the eighteenth century, especially against the revivalisms in the nineteenth century when almost all historical styles - Greek, Roman, Romanesque, Gothic, Renaissance, Baroque, Rococo - were revived one after another.

However, postmodern architecture emerged in the 1960s as a reaction against the austerity, formality and lack of variety of modern architecture, particularly in its International Style. The postmodern architecture movement was mainly started by Robert Venturi (1925-2018) and Denise Scott Brown (1931-). ${ }^{3}$ Starting with a few publications by Charles Jencks (1939-) in the 1970s, the terms postmodern architecture and postmodernism started to be widely used all over the world. ${ }^{4}$ Postmodernism thrust modernism which split off from historical revivalism into historical styles. Modern architecture, represented by the International Style, became one of the main historical styles in the 1960s-1980s. Deconstructivism is a subset of postmodernism in a broad sense, but it is opposed to postmodern classicism. It was a new development from Russian constructivism.

\section{GEOGRAPHY OF CONTEMPORARY ARCHITECTURE}

There is a world history, as well as the unique history of each region, each country and each area. Although each continent has its continental geography, the geography of each region or country or area is a specific one. Especially in the Eurasian continent, the geography of each of the areas in the north, south, 
east and west is very different. Human geography and history are closely linked. Physical geography deals with the study of processes and patterns in the natural environment. Although it is not closely linked with history, physical geography is also important to understanding the architectural history and contemporary architecture of each country.

Although Japan is considered one of the safest countries in the world, the continuous process of subduction causes frequent earthquakes. The Japanese islands are also affected by typhoons. Japan is a country subject to numerous natural disasters, but it is a country which recovers relatively quickly and is considered safe. The history of contemporary architecture is not related to natural disasters in the West and in several other parts of the world. In Japan, however, it is impacted by the occurrence of earthquakes.

Two major earthquakes hit Kansai and Tohoku in 1995 and 2011, respectively, after the 1923 Great Kanto earthquake in Tokyo. In a sense, Japan had major earthquakes in the beginning of modernism and at the peak of postmodernism or more properly deconstructivism. History of contemporary architecture in Japan should be written with the focus on earthquakes or at least with the related activities of contemporary architects.

Tadao Ando (1941-) is an architect who is still propagates modern architecture in Japan. When we observe his design and completed buildings, we may feel that modern architecture still exists. Although it is not necessary to talk about earthquakes when referring to Ando's work, it is very important to think about it in relation to the work of Toyo Ito (1941-), who is a contemporary of Ando. They made their architectural debuts almost simultaneously in 1976. Ito's White-U built in Tokyo is an exposed concrete house and so is Ando's Sumiyoshi-noNagaya built in Osaka. Between 1982 and 1984, Ito took a different direction with his own house Silver Hut built next to his elder sister's White-U. Since the completion of Silver Hut, Ito has been exploring flexibility, openness and transparency or translucency in contrast to the solidness of Ando's architecture.

The Sendai Mediatheque designed by Ito and completed in 2001 was conceived as a transparent cube through which thin floor plates float suspended on organic-looking seaweed-like tubes. It is a new reinterpretation or a gentle deconstruction of Le Corbusier's Dom-ino house and comparable to the Centre Pompidou designed by Renzo Piano (1937-) and Richard Rogers (1933-). It is, however, more harmoniously blended together with or melted into the cityscape by using glass façades, which through their variable reflections and 
transparency allow the building to alternately dematerialise itself, creating a kind of ephemeral connection with infinite space. Ito explains its inventive tube structure by showing seaweeds in a glass case and the phenomenal ephemerality of its façades and the flexibility of interior partitions by touching upon traditional Japanese architecture. The Great Tohoku earthquake, which occurred in northeastern Japan on March 11, 2011, was also called the Great Sendai earthquake. The Sendai Mediatheque, a building of light image was structurally strong, and remained relatively unscathed from the earthquake. It was temporarily a relief centre in Sendai, the largest city in the Tohoku region and the second largest city north of Tokyo.

More modern elements of Ito's architecture, such as slick and clean surfaces made of glass and metals, are also used by one of his successors, Kazuyo Sejima (1956-). After apprenticing with Ito, Sejima established Kazuyo Sejima \& Associates in 1987, and in 1995, the Tokyo-based firm SANAA (Sejima and Nishizawa and Associates) with Ryue Nishizawa (1966-), who had worked with Sejima at Toyo Ito \& Associates and Kazuyo Sejima \& Associates afterward.

SANAA uses large windows which allow natural light to enter a space and create a fluid transition between the exterior and the interior. The Kanazawa

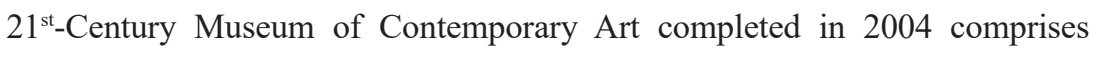
a circular building, 112.5 meters in diameter, with no main façade or main entrance. Designed without a front or back, the central area of the museum is used for temporary exhibitions. The museum also has a number of public spaces which include a library, lecture halls and workshops. ${ }^{5}$ Interspersed with the public spaces of the museum are some permanent installations open to the public free of charge. These installations include works such as "Swimming Pool" by Leandro Erlich, a pool where people appear to be underwater, and "Blue Planet Sky" by James Turrell, a space exploring blue sky as a medium. "Blue Planet Sky" is a small sky and "Swimming Pool" is a small sea. This circular-plan museum building could be a small model of the earth.

A structural design and building construction are also very important in an earthquake-prone country. Advanced structural engineer Mutsuro Sasaki (1946-) has teamed with Japanese architects Toyo Ito, Arata Isozaki (1931-) and SANAA, to help bring to life free-flowing forms of organic architecture, such as the Sendai Mediatheque and the Kanazawa $21^{\text {st }}$-Century Museum. The steel columns of the Kanazawa $21^{\text {st }}$-Century Museum are slender, ranging from $95 \mathrm{~mm}$ to $110 \mathrm{~mm}$. By using many steel braces in the walls of galleries for the north-south and east-west directions, the almost transparent building of the museum was achieved in the snowy Japanese city of Kanazawa in Japan. ${ }^{6}$ 
The Kanazawa $21^{\text {st }}$-Century Museum can be compared with the MAXXI National Museum of the XXI Century Arts, another twenty-first century museum designed by Zaha Hadid (1950-2016), which was completed in Rome in 2010. The very striking building received the Royal Institute of British Architects Stirling Prize in the same year. It is dynamic and sculptural, not only in its exterior but also its interior with large ramps and stairs. The Guggenheim Museum Bilbao, designed by Frank Gehry (1929-) and opened in 1997, is one of the first and most important museums of deconstructivism. It was opened as part of the revitalization efforts for the city of Bilbao. Immediately after its opening, the Guggenheim in Bilbao became a very popular tourist attraction, drawing visitors from around the world. Even now it attracts a great number of visitors. An unexpected aspect of the museum is that most visitors watch and experience the building more enthusiastically than works of art exhibited inside its galleries. The Guggenheim Museum Bilbao is a gigantic sculpture and a huge jewel made of titanium panels along the Nervion River (Figure 1).

Louvre-Lens, which was designed by SANAA and opened in Pas-de-Calais, northern France, in 2012, is a development from the Kumanokodo Nakahechi Museum, which was completed in 1996 as their first project and opened in 1997. Therefore, it is appropriate to compare Louvre-Lens with the Guggenheim Museum Bilbao and the museums in Rome and Kanazawa as important museums designed at the turn of the century. The Kumanokodo Nakahechi Museum was the first museum designed by SANAA. It is a small museum built in a mountainous part of Tanabe City, registered as a World Heritage Site. ${ }^{7}$

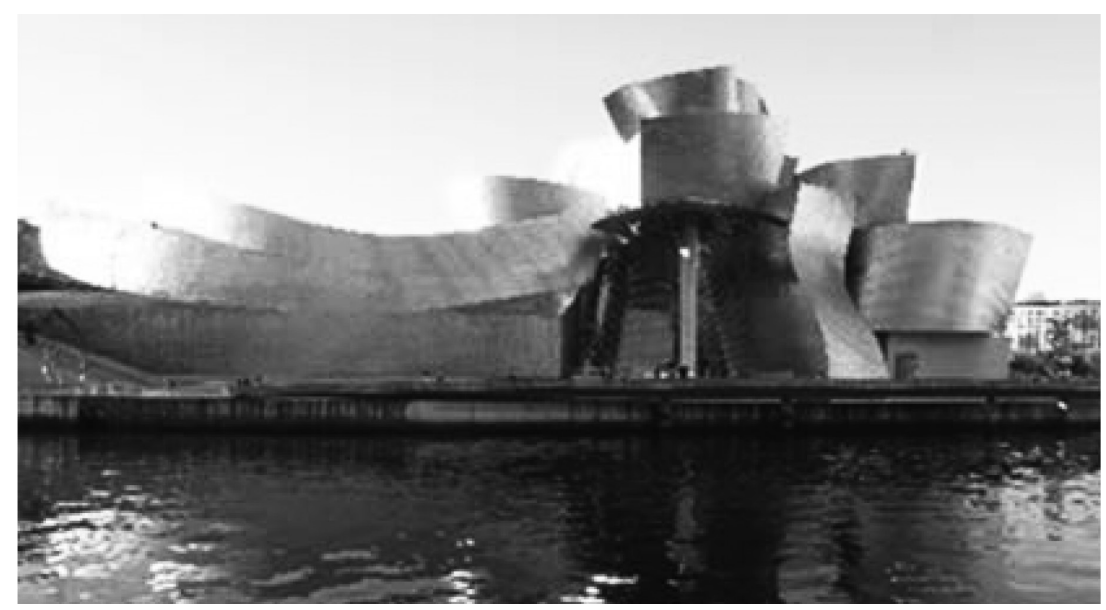

Frank Owen Gehry, Guggenheim Museum Bilbao, Spain (Photo by the author) Fig. 1. 
The architects designed the Louvre-Lens as a string of five low-profile structures. The central one is a square with glass walls and the others are rectangular with polished aluminium façades, giving a blurry reflection of the surroundings. Altogether, the museum is 360 -meters long and contains three exhibition spaces. The square-shaped, central building is the main reception area. It contains several round glass rooms that include an information centre and a museum shop. The building to the west of the entry hall is a gallery for temporary exhibitions. Its round curtained spaces like round glass rooms in the central building are often used for exhibitions. In traditional museums, there are many rooms, which are used for various sections of temporary or permanent displays and showpieces hung on the wall. Walls are not used for temporary exhibitions at the Louvre-Lens, rather showpieces are exhibited in these round curtained spaces, with titles and outlines of artwork printed on translucent curtains. This allows visitors to see the exhibition's and separate sections at the same time or one after another.

To the east of the entry hall is the Galerie du Temps (Grande Gallerie), which houses approximately 200 objects from the collection of the Louvre, Paris. The showpieces in the large, open hall are arranged chronologically, dating from 3,500 BC to the mid-nineteenth century. With more than 380,000 artworks at the Louvre Paris, the collection is divided into main buildings which are further subdivided into rooms in each building. Although the number of showpieces is much smaller in the Louvre-Lens, visitors can view the whole history of Western art by walking through the Galerie du Temps. In comparison with the Guggenheim Museum Bilbao and the National XXI Century Museum in Rome, the Louvre-Lens is not sculptural but transparent or translucent. In a sense, SANAA pays more attention to exhibition spaces than the museum building itself.

Philip Johnson (1906-2005), a late architect and the first curator of the "Deconstructivist Architecture" exhibition held at the Museum of Modern Art, New York, in 1988, said deconstructivist architecture is not a new style. He also wrote that deconstructivist architecture is not a movement. Associate curator of the exhibition, Mark Wigley (1956-), also wrote that deconstructivist architecture is not an '-ism'. ${ }^{8}$ There are scarcely any architects who call themselves deconstructivists. However, deconstructivist architecture is regarded rather positively in the West, particularly in many international competitions. In Japan, postmodernism and deconstructivism are not widely spread. An exceptional architect is Kengo Kuma (1954-) whose work should be compared with that of Peter Eisenman (1932-). 
Eisenman designed a few buildings in Tokyo in the 1980s. Although deconstructivism does not mean destructivity, works by Frank Gehry and Eisenman include the multi-storeyed buildings in which construction and destruction are superimposed. Eisenman designed the Koizumi Lighting Theatre, which was built in 1988-1990 and the Nunotani Building in 1992. Such buildings can be constructed on the US East Coast because there are hardly major earthquakes. In Japan, however, the Nunotani Building was demolished after the 1995 Great Hanshin earthquake and before the 2011 Tohoku earthquake. The Koizumi Lighting Theatre was renewed after the Tohoku earthquake in 2011.

Kuma designed the M2 building (Memolead Tokyo), which includes a postmodern huge Ionic column-shaped tower and destructive outside stairs, in 1991. He is an exceptional architect who tried to design and develop works which combine postmodern classicism and deconstructivism. Before M2, Kuma designed the Small Bathhouse in Izu in 1988, similar to the Frank Gehry Residence. In the US, deconstructivism was developed in contrast to postmodern classicism. Kuma, was open to both styles as a young architect.

He completely changed his style around the time of the Great Hanshin earthquake in 1995, by developing minimalistic and naturalistic buildings. In 1994, he designed the Kirosan Observatory. In the same year, he published Shin Kenchiku Nyumon (Introduction to New Architecture) in November, and Kenchikuteki Yokubo no Shuen (The End of Architectural Desire) in December. In 1996, he published Kenchiku no Kiki wo Koete (Beyond the Crisis of Architecture). The observatory is described as follows: 'This project focused on anti-disposition of objects in nature. Kirosan Observatory appears as a single narrow slit inside the hillside. This has reversed the concept that is embedded in our daily life that any observation platforms typically expose their presence by simply standing amidst the natural environment'. ${ }^{9}$ The Kitakami Canal Museum, built in 1999, is also a minimalist, naturalist work.

Kuma started to use louver in large-scale in his architecture in the late 1990s and designed three museums in Nasu: the Stone Museum, the Nasu Historical Museum, and the Batō Hiroshige Museum in 2000. In the Stone Museum, horizontal stone louvers were introduced to create a unique lighting effect on the inside. He used wood louvers for the other two museum buildings, starting concentrating on Japanese wooden timbering. 


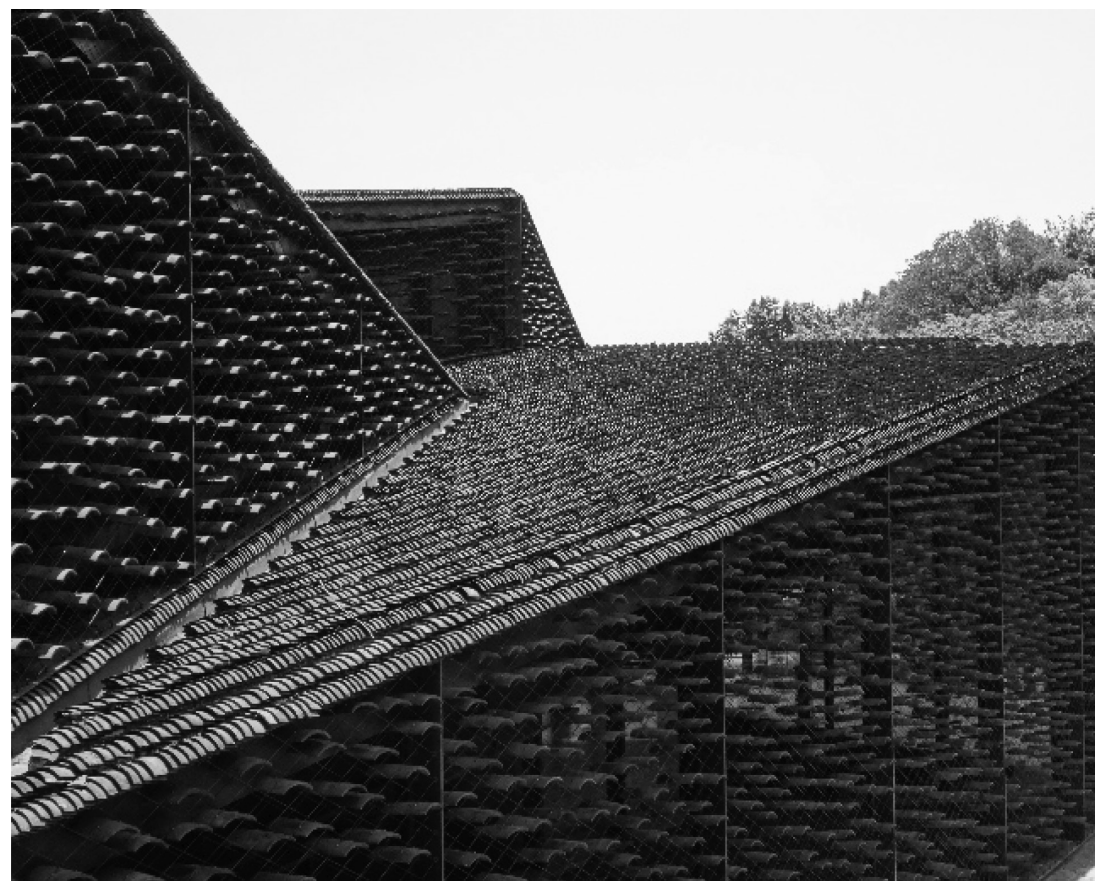

Fig. 2. Kengo Kuma, The Folk-Art (Crafts) Museum, China Academy of Art, Hangzhou, China (Photo by the author) 
For the Xinjin Zhi Museum of China, completed in 2011, Kuma used the permeable screen façade made from locally available tiles. An airy screen was created by fixing the tiles that naturally have a rough texture made at local workshops, using traditional techniques with stainless steel wire. The Folk-Art (Crafts) Museum of the China Academy of Art in Hangzhou was built in 2015 (Figure 2). It is described as follows: 'Each unit has a small individual roof, so the overall image evokes a village with extended tiled roofs. ... The outer wall is covered with a screen of tiles hung up by stainless steel wires, which in turn controls the amout of sunlight coming into the rooms. ... Old tiles for both the screen and the roof come from local houses. ${ }^{10}$ Kuma also used these tiles for airy screens as seen in the Xinjin Zhi Museum. Unlike SANAA's Sejima and Nishizawa, Kuma conceptualises his architecture based on the history and geography of the construction location.

He used the term 'brise-soleil' only to refer to the Fonds régionaux d'art contemporain (FRAC) in Marseille, built in 2012: 'Le Corbusier attempted to solve the problem of light with brise-soleil by defecting sunlight, but we attempted to solve this problem by using particles (panels)'. ${ }^{11} \mathrm{He}$ often uses another term 'louver'. He also wrote about André Malraux: 'Creating an "Art museum without walls" is an idea that was proposed by André Malraux in 1947, and we attempted to add to this concept by using an ambiguous façade'. ${ }^{12}$ Kuma is aware of contemporary history in addition to historical geography.

Unlike Ando or Ito, who started from modernism, Kuma is an architect who started from postmodernism and deconstructivism. As explained above, he made an extreme example of postmodern classicist and deconstructivist architecture in Tokyo. Around the time of the Great Hanshin earthquake, Japan's worst earthquake in the twentieth century after the Great Kanto earthquake occurred during the period of modernism, he left postmodernism and deconstructivism for a kind of minimalist and naturalist style, and then, started to use louvers in various forms and materials.

However, his louvers gradually became more artistic or decorative rather than functional. Although he is an architect with an extreme character, he is also an active and positive person. He was 34 when he made a Small Bathhouse in Izu, which was influenced by Frank Gehry, and 37 when he made the M2 Memolead in Tokyo. In one of his recent works, V\&A Dundee, he still used louver or brise-soleil, but in a slightly less decorative way. He was thinking about the beautiful cliffs of the Orkney Islands in the north of Scotland. Kuma may gradually change his style again. 


\section{EPILOGUE :}

\section{HISTORY AND GEOGRAPHY FOR CONTEMPORARY ARCHITECTS}

Unlike Kuma, Sejima and Nishizawa are not very conscious of the history and geography of architecture. However, some of their works seem to be related to traditional Japanese architecture. Both the Kumanokodo Nakahechi Museum and the Louvre-Lens can be compared to the Katsura Imperial Villa built in a district of Kyoto in the seventeenth century. Although most of SANAA's buildings do not have traditional sloping roofs, the simple façade of glass and aluminium looks like those of the Katsura Villa with simple shoji screens in a beautiful composition.

The asymmetrical plan of the Louvre-Lens may partly look like that of the Katsura Villa. The Louvre-Lens is surrounded by its site with green grass and concrete, which vaguely looks like a traditional Japanese garden with grass or moss and stones laid also asymmetrically (Figure 3). The large windows allow natural light to enter the interior space and create a fluid transition between the interior and the exterior, which is characteristic of traditional Japanese residences. Unlike Kuma, SANAA does not use large louver or brise-soleil. Instead, they use translucent curtains or thin blinds for large windows, which are similar to sudare (reed screen) used in traditional Japanese buildings such as the Katsura Villa. The ceiling is relatively low and its height is equal throughout, unlike museums by Gehry or Hadid. The interiors of SANAA's museums are made with transparent glass and are partly movable like shoji or fusuma in Japanese houses.

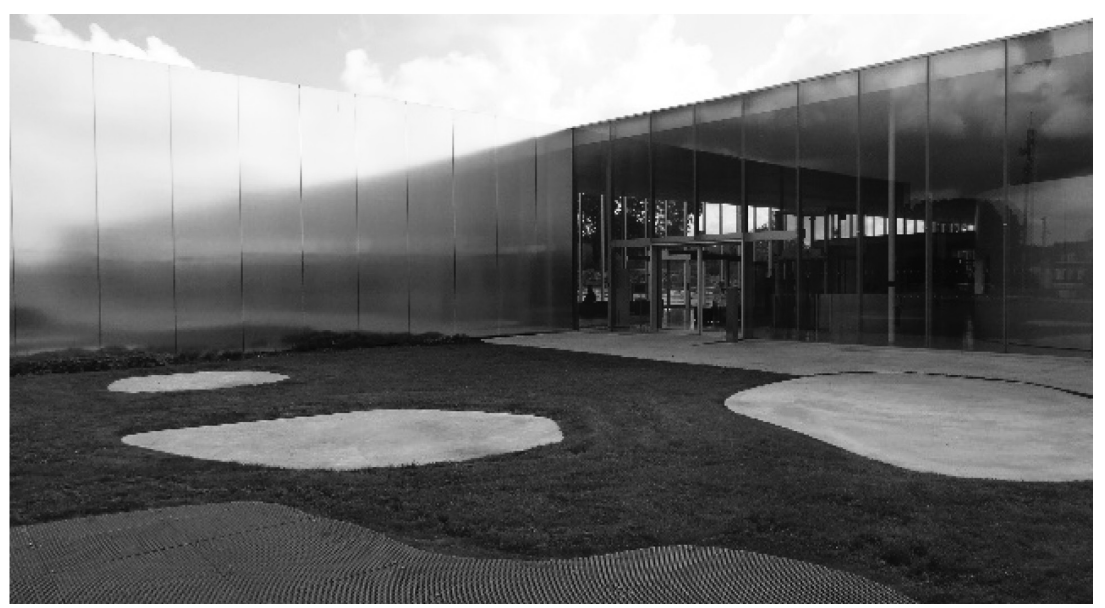

Fig. 3. SANAA (Kazuyo Sejima + Ryue Nishizawa), Louvre-Lens, France (Photo by the author) 
Kuma is conscious of and positive about the history and geography of his building sites in various countries. Although Sejima and Nishizawa also conduct their research on the history and geography of their building sites, they do not insist on it as much as Kuma. They are more transparent or translucent about it, in a similar way to the style of their architecture.

While comparing contemporary architecture in the West and Japan, and among several architects in Japan, I started asking myself when "contemporary history" will change from its start around 1945 and when "contemporary architecture" will change from its style in the twentieth century. It is almost impossible to predict this, just as nobody could know when the new "contemporary history" would start until the world wars. Nevertheless, today's "contemporary history" may end at some point in the twenty-first century, paving the way for a new "contemporary history" and "contemporary architecture". 
Geoffrey Barraclough, An Introduction to CONTEMPORARY HISTORY (New York: Basic Books, Inc., 1964), 1-35.

2 Mark Girouard, Sweetness and Light: The "Queen Anne" Movement, 1860-1900 (New Haven: Yale University Press, 1984).

Robert Venturi, Complexity and Contradiction in Architecture (New York: Doubleday, c. 1966); Robert Venturi, Denise Scott Brown, and Steven Izenour, Learning from Las Vegas: the forgotten symbolism of architectural form (Cambridge, Mass.: MIT Press, c.1977). Charles Jencks, The Language of Post-Modern Architecture (New York: Rizzoli, 1977). Yukio Futagawa (ed.), GA Architect, 18, Kazuyo Sejima, Ryue Nishizawa 1987-2006 (Tokyo: A.D.A. EDITA Tokyo), 116-131.

Mutsuro Sasaki, FLUX STRUCTURE (Tokyo: TOTO Shuppan, 2005), 9-93; Mutsuro Sasaki, Kōzō, Kōchiku, Kenchiku, (Tokyo: LIXIL Shuppan, 2017), 222-225, 238-241. Yukio Futagawa (ed.), GA Architect, 18, Kazuyo Sejima, Ryue Nishizawa 1987-2006 (Tokyo: A.D.A. EDITA Tokyo), 72-75. Philip Johnson and Mark Wigley, Deconstructivist Architecture (Boston: Little, Brown and Company) 7-9, 10-20. https://kkaa.co.jp/works/architecture/kiro-san-observatory/. Ibid. https://kkaa.co.jp/works/architecture/frac-marseille/. 
Barraclough, Geoffrey. An Introduction to CONTEMPORARY HISTORY. New York: Basic Books, Inc., 1964.

Futagawa, Yukio. (ed.), GA Architect, 18, Kazuyo Sejima, Ryue Nishizawa 1987-2006. Tokyo: A.D.A. EDITA Tokyo.

Girouard, Mark. Sweetness and Light: The "Queen Anne” Movement, 1860-1900. New Haven: Yale University Press, 1984.

Jencks, Charles. The Language of Post-Modern Architecture. New York: Rizzoli, 1977.

Johnson, Philip and Mark Wigley, Deconstructivist Architecture. Boston: Little, Brown and Company.

Sasaki, Mutsuro. Flux Structure. Tokyo: TOTO Shuppan, 2005.

Sasaki, Mutsuro. Kōzō, Kōchiku, Kenchiku. Tokyo: LIXIL Shuppan, 2017.

Venturi, Robert. Complexity and Contradiction in Architecture. New York: Doubleday, c. 1966;

Venturi, Robert, Denise Scott Brown and Steven Izenour. Learning from Las Vegas: the forgotten symbolism of architectural form. Cambridge, Mass.: MIT Press, c.1977. 


\section{ISTORIJA I GEOGRAFIJA SAVREMENE ARHITEKTURE \\ Haruhiko Fujita}

Istorija je proučavanje prošlosti opisano u pisanim dokumentima. Praistorija je istorija ljudske kulture pre pisanih dokumenata, a post-istorija je period u kom je dostignut kraj ljudskog razvoja. Savremena istorija, podskup moderne istorije, opisuje istorijsko razdoblje od otprilike 1945. godine do danas. Iako se termin "savremenu istorija" koristi najmanje od devetnaestog veka, njegova upotreba se promenila u dvadesetom veku. Kontinuirani proces subdukcije uzrokuje česte zemljotrese u Japanu. Japanska ostrva takodje pogadjaju česti tajfuni i globalno zagrevanje. Iako je zemlja pogodjena brojnim prirodnim katastrofama, oporavlja se relativno brzo i smatra se sigurnom. Istorija savremene arhitekture na zapadu nije povezana sa prirodnim katastrofama. Medjutim, u Japanu je ona povezana sa zemljotresima. Istoriju savremene arhitekture u Japanu bi trebalo napisati uzimajući u obzir fenomen zemljotresa ili barem način na koji su savremeni arhitekti pristupili ovom pitanju. Nakon vrhunca postmodernizma i dekonstruktivizma, neki japanski arhitekti počeli su da u velikoj meri uvažavaju tradicionalnu kulturu i prirodu, odustajući od postmodernog klasicizma. Značajno je da se iz ovog ugla obrati pažnja na istoriju i geografiju savremene arhitekture u Japanu.

KLJUČNE REČI: ISTORIJA, GEOGRAFIJA, PRIRODA, STVORENO OD STRANE LJUDI, POSTMODERNIZAM, DEKONSTRUKTIVIZAM, SAVREMENA ARHITEKTURA

\section{KOLEKTIVNO RAZMIŠLJANJE-AKCIJA: \\ $O$ DRŽANJU PREDAVANJA, TRANSMEDIJSKOM ZNANJU I PROJEKTOVANJU MOGUĆIH SVETOVA}

\section{Jon McKenzie}

Izbor Donalda Trampa je razotkrio politiku prezira koja pravi podelu medju seoskim i gradskim stanovništvom, kao i medju zajednicama i koledžima. Ova podela seže u prošlost sve do Platonove akademije. Kada je Platon proterao pesnike iz Republike, on je izbacio prakse poput poezije, muzike i plesa iz oblasti istinskog, epistemskog znanja, koje je bilo u suprotnosti sa doksom ili opštim znanjem. Vekovima kasnije, ova opozicija će oblikovati pristup evropskog kolonijalizma prema autohtonim živim svetima, čiji će se ,primitivni” obredi, mitovi i fetiši suprotstaviti „civilizovanim” metodama, istorijama i predmetima zapadnog znanja. Upravo te suprotnosti čine strukturu ideoloških kritika popularne kulture. Medjutim, pojava predavanja, teorije repa i informacija u vidu stripova na istraživačkim univerzitetima dvadeset prvog veka ukazuje da je tradicionalna proizvodnja znanja pod pritiskom unutar i izvan akademske zajednice. Znanje u nastajanju (eng. emerging) je transmedijsko znanje koje uključuje različite publike mešajući epistemu i doksu. Ovde je u pitanju: uloga estetike u postdisciplinarnim društvima kontrole i u otpornim modalitetima kolektivnog razmišljanja i akcije. I u umetnosti i nauci naučnici širom sveta se okreću znanju transmedije ne samo radi komunikacije već i radi zajedničkog stvaranja istraživanja. Ovde transmedijsko znanje može funkcionisati kao građanski diskurs i kao provodnik generalizovane estetike 